\title{
Foreword: Inertia and innovation in inter-disciplinary social science
}

\author{
By Paul Webley (School of Oriental and African Studies)
}

Social scientists use a wide variety of methods and analytical techniques, with some focusing on the individual, others on very small groups, and still others on huge samples of the population. So an interested general reader dipping into social scientific research might encounter transcripts of conversations analysed with great subtlety, experiments carried out in computer laboratories or complex statistical analysis of survey data. Disciplines within social science have different traditions and different epistemologies, so the neophyte researcher is exposed to and trained in very different kinds of approaches depending on whether they are a social anthropologist, a geographer, an economist, demographer, psychologist or sociologist. The research questions they seek to answer, however, very often cross disciplinary boundaries, so there is a danger that disciplinary affiliation can act as a straightjacket, which can constrain the choice of research method and restrict an appreciation of relevant research carried out by those in other disciplines.

For most of my academic career I have been working in economic psychology, and trying to ensure that my work both draws on and feeds back to the two parent disciplines of economics and psychology (Webley et al 2001). In terms of methods, this has presented serious problems. Psychologists base much of their research on what people 'say' - in one-to-one interviews, focus groups, experiments and so forth or 'write' - in questionnaires, surveys, psychometric tests and so on. Economists, at least those of the traditional sort, are extremely dubious about 'what people say' and suspicious of the value of data gathered from interviews and questionnaires. They are particularly doubtful of 'un-priced' statements where people assert preferences in the absence of any cost of their behaviour. For example research that shows, using questionnaires and experiments, that people will willingly sacrifice financial returns in order to invest ethically (Lewis et al 1998) is treated with a great deal of scepticism. Economists generally want data based on what people actually do: what people say is seen as some kind of epiphenomenon or, at best, a very weak guide to 'real' behaviour.

Here I will briefly discuss two examples of research in economic psychology that give some idea of the kind of issues that are involved in working at the intersection of two disciplines with very different ideas of appropriate and authentic methods.

The first was associated with the development of an economic psychological approach to money, based on an adaptation of Lancaster's characteristics theory of consumer demand (Lancaster 1966). This focused our attention on the range of psychological characteristics that money possesses and then on the question of how these characteristics affect behaviour with and towards money. The changeover from the $£ 1$ note to the $£ 1$ coin in the United Kingdom in April 1983 provided an opportunity to look at this question - what are the consequences for behaviour of a change in the physical form of money?

This change was not uncontroversial. It was front page news (the Daily Mail used as a headline "The pound coin that Britain doesn't want") and received extensive and mostly negative media coverage. Our intention was to carry out a very simple study just to confirm the intuition that 
making the $£ 1$ unit a coin, rather than a note, would turn it psychologically into 'small change', which would mean that it would be spent rather differently. Our approach was to obtain a sample of respondents who agreed that we could examine the contents of their wallets and purses everyday for a month. Each note and coin was marked with a special fluorescent pen, so that the marks could only be seen when the note or coin was viewed using a special lamp. This meant that the average dwell time - the time spent in a wallet - of each monetary unit could be calculated. The results revealed a U-shaped relationship between value and dwell time (small value coins and large value notes spent the longest time in people's purses) (Webley, Lea, Hussein 1983). Unfortunately the number of $£ 1$ coins in circulation was too small to draw firm conclusion, though for each participant who had received $£ 1$ coins their dwell time was less than for $£ 1$ notes. A subsequent study, which involved paying people for their participation in an unrelated experiment with either a $£ 1$ note or $£ 1$ coin, confirmed the finding that the coins were spent quicker than the notes.

We were quite pleased with this very simple study: the research method was certainly novel, and it did demonstrate the result we expected. The reaction of most economists in this case, however, was to dismiss this as simply of no interest. Whilst we had looked at people's behaviour, it was a behaviour that was a minor aberration, of no theoretical import, and was in any event only a transitional issue since people would soon get used to the new coins. Our own interpretation was rather different: we believed we had identified an issue of general interest (where the note/coin boundary is placed and its impact on behaviour) as well as devised a new method that might have other applications.

The second example involves research carried out over a number of years into tax evasion and tax compliance. Here there is no doubt that behaviour matters (both financially and theoretically). There is a large literature in economics on tax compliance, a number of competing theoretical models and a lot of data gathered in a variety of ways (see Andreoni, Erard, Feinstein 1998). There is also quite an extensive literature in general social science and economic psychology, with sociological and economic psychological models of compliance (Kirchler 2007).

One of the approaches I developed was to set up computer simulations, where participants would be running a business (landscape gardening in one early version, a restaurant in a later version) (Webley et al 1991). In running the business they would have to make a series of decisions about where to advertise and how much to spend on this, on pricing, on menus and so on. And, as one of the decisions they would be making, they would make a tax return (in some studies a quarterly VAT return as well) (Webley, Adams, Elffers 2006). This means that one has created a context where people can decide to evade tax or not but of course the situation is not 'real' - no money is involved, and though there are consequences within the simulation of being caught evading (that is, 'a fine'), these are not real world consequences. Nonetheless the results obtained from this kind of approach provide useful evidence and are consistent with some theoretical models.

Critics of this kind of approach would say that since one is not measuring real tax evasion, the results are of limited importance. To explore this further, Elffers, Robben and Hessing (1992) carried out a study where they looked at people's tax behaviour in three ways. First, they had, through the co-operation of the Dutch tax authorities, officially measured tax compliance. This was assessed by tax inspectors based on the information available in people's tax returns. Second, they had self-reported tax compliance. This was measured using a detailed questionnaire. And finally they had tax compliance measured in a simulation of the type described above. The logic of this kind of approach is what has been called 'methodological triangulation'- where the researcher 'homes in' on the correct answer. What was found in this case was that whilst it was 
possible to predict tax behaviour as measured in a simulation, or officially, or by self-reports, there was little overlap between the different measures. This left the researchers somewhat bemused about what conclusions to draw. It certainly was not the case that the officially measured tax evasion was the benchmark against which the others should be compared. It is clear, from other studies, that officially measured evasion is not very reliable, and of course only assesses evasion that has been detected by the tax authorities. Self-reported evasion also has its problems: some people are not able or willing to acknowledge that they have evaded, and others appear to boast about evasion that has not actually occurred. Simulated evasion is in some sense hypothetical behaviour which looks at what people might do in a given situation.

The reaction to this particular research, the only study I am aware of that has compared all three approaches, has been illuminating. Researchers have carried on using all three of these methods. Economists have favoured using official records and have also used experiments similar to the simulation methods described above, though with the important difference that the experiments have a monetary incentive structure. Economic psychologists have continued to use all three methods, but have concentrated more on questionnaires. What this illustrates is inertia in the use of research methods. Social scientists use research methods that they have been trained in and are comfortable with, and which journals will publish: they are therefore reluctant to relinquish them or move on to master new approaches.

So my conclusion is that it is essential that we all reflect on our own practices as researchers, and be prepared to move out of our comfort zones and understand and embrace research methods that come from other disciplines. But we should also be seeking always to devise new methods which will help all of us in social science to understand the complex world in which we live. That is why this special issue, and the conference on Exploring and Expanding the Boundaries of Research Methods on which it is based, is so important, and why we at SOAS were so pleased to be involved. The conference certainly helped the participants, who were themselves from a wide range of disciplinary backgrounds, reflect on their own practice as researchers, but I think that it also stimulated them to begin to devise new approaches which may help us all. I hope the special issue will have the same effect on its readers, and encourage the kind of dialogue, debate and innovation that is at the core of the development of good social science.

\section{References}

Andreoni, J., Erard, B., and Feinstein, J. 1998. Tax compliance. The Journal of Economic Literature 36:670-701.

Elffers H., Robben, H.S.J., and Hessing, D.J. 1992. On measuring tax evasion. Journal of Economic Psychology 13:545-567.

Kirchler, E. 2007. The Economic Psychology of Tax Behaviour. Cambridge: Cambridge University Press.

Lancaster, K.J. 1966. A new approach to consumer theory. Journal of Political Economy 74:132-157.

Lewis, A., Webley, P., Winnett, A., and Mackenzie, C. 1998. 'Morals and markets: Some theoretical and policy implications of ethical investing', in P. Taylor-Goodby (ed) Choice and Public Policy: The Limits of Welfare Markets. Macmillan: Basingstoke.

Webley, P., Adams, C.J. and Elffers, H 2006. 'Value Added Tax Compliance', in E.J. McCaffery and J. Slemrod (eds.), Behavioral Public Finance: Toward a new agenda. New York: Russell Sage.

Webley, P., Burgoyne, C.B., Lea, S.E.G. and Young, B.M. 2001. The Economic Psychology of Everyday Life. Hove: Psychology Press.

Webley, P., Robben, H., Elffers, H., and Hessing, D. 1991. Tax Evasion: An Experimental Approach. 
Cambridge: Cambridge University Press.

Webley, P., Lea, S.E.G., and Hussein, G. 1983. A characteristics approach to money and the changeover from the 1 pound note to 1 pound coin. Paper presented at the $8^{\text {th }}$ International Symposium on Economic Psychology, Bologna.

\section{About the Author}

Professor Paul Webley is Director and Principal of the School of Oriental and African Studies. He can be contacted at pw2(AT)soas.ac.uk. 